\title{
Can telemedicine be effective in responding to local health needs? Insights from the experience of Piedmont Region in Italy
}

Le développement de la télémédecine dans la région du Piémont (Italie) : entre contraintes régionales et besoins locaux

Bibiana Scelfo, Marco Grosso, Marco Dalmasso, Stefania Bellelli, Chiara Rivoiro, Valeria Romano, Marta Alesina, Matteo Ballesio, Michele Presutti, Michele Ceruti, Alberto Lazzero and Sylvie Occelli

\section{OpenEdition}

Electronic version

URL: https://journals.openedition.org/rfst/1457

DOI: $10.4000 /$ rfst.1457

ISSN: 2492-3672

Publisher

Espaces et SOciétés (UMR 6590)

Electronic reference

Bibiana Scelfo, Marco Grosso, Marco Dalmasso, Stefania Bellelli, Chiara Rivoiro, Valeria Romano, Marta Alesina, Matteo Ballesio, Michele Presutti, Michele Ceruti, Alberto Lazzero and Sylvie Occelli, "Can telemedicine be effective in responding to local health needs? Insights from the experience of Piedmont Region in Italy", Revue francophone sur la santé et les territoires [Online], Decentralization and territorialization of health, Online since 03 January 2022, connection on 09 January 2022. URL: http:// journals.openedition.org/rfst/1457 ; DOI: https://doi.org/10.4000/rfst.1457

This text was automatically generated on 9 January 2022.

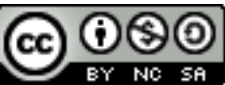

La Revue francophone sur la santé et les territoires est mise à disposition selon les termes de la Licence Creative Commons Attribution - Pas d'Utilisation Commerciale - Partage dans les Mêmes Conditions 4.0 International. 


\title{
Can telemedicine be effective in responding to local health needs? Insights from the experience of Piedmont Region in Italy
}

\author{
Le développement de la télémédecine dans la région du Piémont (Italie) : entre \\ contraintes régionales et besoins locaux
}

Bibiana Scelfo, Marco Grosso, Marco Dalmasso, Stefania Bellelli, Chiara Rivoiro, Valeria Romano, Marta Alesina, Matteo Ballesio, Michele Presutti, Michele Ceruti, Alberto Lazzero and Sylvie Occelli

\section{Introduction}

1 Telemedicine (TM) concerns the provision of healthcare, through ICT, regardless of where people involved (professionals and patients) are located.

2 For an ageing population, as in Piedmont, these services can have a fundamental role to respond to health needs of the elderly in which, chronic diseases are more prevalent and whose access to healthcare is more difficult.

3 TM and information technologies are fundamental to overcome these issues. They can optimise waiting lists, facility costs and service quality, provided they are appropriately introduced.

4 In order to define an accreditation pathway and include TM into the public healthcare system, in 2017, the Health Department of Piedmont, in collaboration with the authors, conducted a survey of Telemedicine projects implemented in the region. A questionnaire was administered to all the public healthcare providers (Aziende Sanitarie Locali, ASL) and investigated main requirements related to appropriateness and effectiveness of the new services. 


\section{Results}

In addition to the identification data of the TM service, the questionnaire gathered information about the economic sustainability of the service, the organisation, the training of both patients and staff and compliance with regulations as specified in the National Guidelines.

The survey allowed to detect 45 projects returning a picture of the regional experience which shows lights and shadows. Concerning the benefits of telemedicine services, the most reported relate to improvement of the patient's quality of life (37\%), while the most critical issue reported was the lack of reimbursement rules and financial support ( $42 \%$ of services, see Fig. 1 ).

Figure 1. Reported benefits and critical issues of telemedicine.

a) Reported TM benefits (\% of projects)

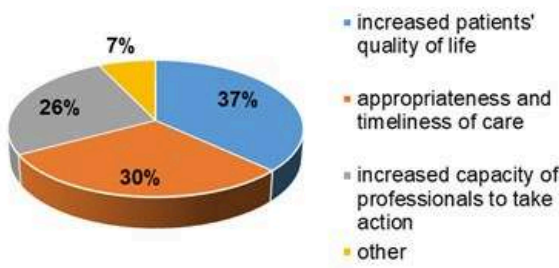

b) Reported TM critical issues (\% of projects)*

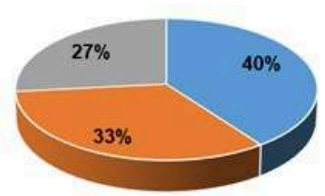

lack of reimboursement and financial support

organisational shortcomings

- technology-related issues

* the percentage was calculated over the 45 projects, some projects reported more than one critical issue

7 The observed criticalities reveal a common denominator: the lack of institutional recognition and of an accreditation pathway to ensure appropriateness of care, adequate investments and economical sustainability.

To complement the analysis, an effort was made to assess the maturity level the surveyed projects. Building on the existing literature and the collected data, the scheme considers five domains, each contributing to the successful implementation of TM and to the improvement of the health organisation: i) users; ii) workflow; iii) technology; iv) financial support; v) governance.

9 TM services were then assessed for each domain, and their normalized score represented on a value interval varying between 0 and 100. By summing up the single values, services' overall score were obtained which can be understood as a proxy of their level of maturity. The average score value for the regional TM initiatives was 266, The domain with the highest score was that related to users (80), followed by that concerning workflow (67), technology (57), financial resources (40) and lastly governance (21).

10 The application of the analytic scheme revealed that those services which are in place since a longer time are more mature. As for the type of service, the same appears to be true for telemonitoring.

11 We also describe two case studies which address the issue of healthcare accessibility in different settings. 

teleradiology service. The results, obtained from a clinical trial, demonstrated benefits in terms of quality of life, satisfaction and costs. However, due to lack of support from the regional administration, the service was terminated.

13 The second case is a cross-border cooperation project between France and Italy where the provision of healthcare was delivered through a shared digital infrastructure allowing professionals and patients, to access healthcare services regardless of their country of origin. Differences in national regulations on public healthcare are still an issue for the integration of the service into practice but the winning aspect was he empowerment of citizens and patients regarding their rights to access and manage their own medical records.

\section{Discussion and conclusions}

Insights from the Piedmont case highlight a few factors which are mandatory for TM sustainability: technological infrastructure, people's readiness and economical recognition. They also point out that a governance process, across national, regional and local levels, is necessary to ensure that those factors are put in place to enable the successful implementation of TM services.

When considering the geographical distribution of the hospitalisation rates for chronic diseases, for example, the analysed TM services seem to have a potential for meeting the residents' health needs. This is coherent with the goals of the regional health plan to reinforce territorial health care.

These issues are even more prominent today in the face of the Covid pandemic, which is pushing innovative technologies, like TM services, to be delivered wherever possible to avoid preventable hospitalisations. However, this situation raises questions about fairness and appropriateness and calls for an increased attention at the assessment of the new as well as of the conventional healthcare services already in practice.

\section{INDEX}

Keywords: Telemedicine, Policy making, cross-border cooperation, eHealth, Public health, Sociotechnical systems, accessibility

Geographical index: Piedmont, Italy

\section{AUTHORS}

\section{BIBIANA SCELFO}

Ires Piemonte,Istituto di Ricerche Economiche e Sociali Via Nizza18, Turin (Italie) 


\section{MARCO GROSSO}

Radiology Unit Public Hospital “Città della Salute e della Scienza”, Turin (Italy). https:// www.researchgate.net/profile/Marco-Grosso-3

ORCID : 0000-0002-7083-0929

\section{MARCO DALMASSO}

Servizio Sovrazonale di Epidemiologia (SEPI) ASLTO3, Grugliasco (Italie)

\section{STEFANIA BELLELLI}

Ires Piemonte,Istituto di Ricerche Economiche e Sociali, https://www.researchgate.net/profile/ Stefania-Bellelli

ORCID : 0000-0002-5315-3954

\section{CHIARA RIVOIRO}

Ires Piemonte,Istituto di Ricerche Economiche e Sociali, https://www.ires.piemonte.it/ index.php/component/tlpteam/team/chiara-rivoiro?Itemid=437

\section{VALERIA ROMANO}

Ires Piemonte,Istituto di Ricerche Economiche e Sociali, https://www.ires.piemonte.it/ index.php/component/tlpteam/team/valeria-romano?Itemid=437

\section{MARTA ALESINA}

S.S. Ricerca e Innovazione Asl TO3, Via Martiri del XXX Aprile 30, Collegno (Italie)

\section{MATTEO BALLESIO}

S.S. Ricerca e Innovazione

\section{MICHELE PRESUTTI}

S.C. Formazione Qualità e Gestione Rischio Clinico delle Attività Sanitarie ASL T03, Via Martiri del XXX Aprile 30, Collegno (Italie)

\section{MICHELE CERUTI}

Centre Hospitalier des Escartons 24, avenue Adrien Daurelle, Briançon (France), ORCID : 0000-0002-5315-3954

\section{ALBERTO LAZZERO}

Pôle de Medecine-Gériatrie et Santé Publique Centre Hospitalier des Escartons, https:// www.Linkedin.com/in/alberto-lazzero-32587719

\section{SYLVIE OCCELLI}

Ires Piemonte,Istituto di Ricerche Economiche e Sociali, https://www.researchgate.net/profile/ Sylvie-Occelli 